\title{
Microstructure and Tribocorrosion Properties of Ni-Based Composite Coatings in Artificial Seawater
}

\author{
Bo $\mathrm{Li}^{1, *}$, Cong $\mathrm{Li}^{1, *}$, Yimin Gao ${ }^{1}$, Hongjian Guo ${ }^{2}$, Yunchuan Kang ${ }^{1}$ and Siyong Zhao ${ }^{3}$ \\ 1 State Key Laboratory for Mechanical Behaviour of Materials, School of Materials Science and Engineering, \\ Xi'an Jiaotong University, Xi'an 710049, China; ymgao@mail.xjtu.edu.cn (Y.G.); \\ kangyc30@stu.xjtu.edu.cn (Y.K.) \\ 2 State Key Laboratory of Solid Lubrication, Lanzhou Institute of Chemical Physics, Chinese Academy of \\ Sciences, Lanzhou 100864, China; chinaghj2019@hotmail.com \\ 3 Guangxi Great Wall Machineries, Hezhou 542800, China; wei9786@163.com \\ * Correspondence: libo616@mail.xjtu.edu.cn (B.L.); licong369@stu.xjtu.edu.cn (C.L.)
}

Received: 6 November 2019; Accepted: 2 December 2019; Published: 4 December 2019

\begin{abstract}
NiAl matrix composite coatings were prepared using atmospheric plasma spraying (APS). The mechanical and tribocorrosion properties of the NiAl matrix composite coatings, incorporated with $\mathrm{Cr}_{2} \mathrm{O}_{3}$ and $\mathrm{Mo}$, were investigated, and the synergistic effect between corrosion and wear was studied in detail. The microhardness of the composite coating improved from 195.1 to $362.2 \mathrm{HV}$ through the addition of $\mathrm{Cr}_{2} \mathrm{O}_{3}$ and Mo. Meanwhile, the $\mathrm{Cr}_{2} \mathrm{O}_{3}$ and Mo phases were distributed uniformly in the composite coatings. The X-ray diffraction (XRD) peaks of Ni-based solid solution slightly shifted to the right after adding the Mo. This was probably due to the solid solution of Mo into the matrix. The NiAl- $\mathrm{Cr}_{2} \mathrm{O}_{3}-\mathrm{Mo}$ composite coating had the lowest corrosion current density, wear rate and friction coefficient of $9.487 \times 10^{-6} \mathrm{~A} / \mathrm{cm}^{2}, 3.63 \times 10^{-6} \mathrm{~mm}^{3} / \mathrm{Nm}$, and 0.18 , in all composite coatings as well as showing excellent tribocorrosion properties.
\end{abstract}

Keywords: tribocorrosion properties; synergistic effect; corrosion current density; worn surface; tribocorrosion properties

\section{Introduction}

With the forward depletion of land sources, it is very hard to satisfy the development needs of industry [1,2]. In recent years, the abundance of ocean resources has attracted researchers' attention [3,4]. Marine equipment has had an important effect on marine exploration, such as ocean wind turbines, vessels and offshore oil platforms. However, ocean equipment easily suffers, not only from direct corrosion, but also the onset of wear, and their combined damage greatly affects the service lives of these kinds of engineering equipment [5-9]. The synergism effect of wear and corrosion is very destructive and usually decided by the reciprocity of chemistry, electrochemistry, mechanics and physics [10,11]. Therefore, corrosion will influence the microstructure, hardness and roughness of worn surfaces, further affecting the wear behavior [12]. In most tribocorrosion situations, the material loss is usually bigger than the simple sum of corrosion and wear $[13,14]$. The synergetic effects of corrosion and wear reduce the service life, safety and reliability of mechanical parts in seawater environments [15]. Therefore, it is imperative to optimize the corrosion and wear properties of mechanical parts in this environment, and to apply coatings with satisfactory mechanical properties. Tribocorrosion is a promising technology, which may provide good protection in ocean environments.

$\mathrm{NiAl}$ intermetallic compounds are considered to be promising materials in marine environments, due to their low density of $5.86 \mathrm{~g} / \mathrm{cm}^{3}$, their high thermal conductivity, their high Young's module of $240 \mathrm{GPa}$, and their high melting point of $1638^{\circ} \mathrm{C}$, as well as excellent corrosion and oxidation 
resistance [16-20]. Nevertheless, the practical application of NiAl has been restricted by its inherent poor ductility at ambient temperatures [21-23]. Acting as a solution-strengthening phase, Mo could improve the strength of materials effectively [24-26]. Meanwhile, Mo could improve the ductility of $\mathrm{NiAl}$ intermetallic compounds at ambient temperatures $[27,28]$. Our previous study on $\mathrm{NiAl}-\mathrm{Mo}_{2} \mathrm{C}$ nanocomposites indicated that the hardness and density of $\mathrm{NiAl}-\mathrm{Mo}_{2} \mathrm{C}$ nanocomposites increased with increasing Mo contents. Meanwhile, the maximum stress and yield strength were all higher than that of NiAl intermetallics [28]. Nevertheless, the NiAl coating has low hardness and suffers severe wear at room temperature [29]. Hence, excellent wear resistant hard phases should be added in the $\mathrm{NiAl}$ protective coating [30]. $\mathrm{Cr}_{2} \mathrm{O}_{3}$, acting as a strengthening hard phase, could, effectively, improve the wear resistance properties and hardness of materials [31-33].

In this work, the mechanical and tribocorrosion properties of NiAl matrix plasma-sprayed composite coatings, incorporated with $\mathrm{Cr}_{2} \mathrm{O}_{3}$ and $\mathrm{Mo}$ in artificial seawater, were investigated, and the synergistic effect between corrosion and wear was studied in detail.

\section{Materials and Methods}

\subsection{Material Preparation}

The NiAl matrix coatings were produced using atmospheric plasma spraying (APS), and the schematic for the preparation of composite coatings is shown in Figure 1. The spray powders of NiAl, $\mathrm{Cr}_{2} \mathrm{O}_{3}$ and Mo were purchased from Sulzer Metco (Winterthur, Switzerland). The mixed feedstock powders were mingled mechanically before spraying. The Inconel 718 substrate was sand-blasted using a sand-blasting machine (Beijing Changkong Sand Blasting Equipment Company Ltd., Beijing, China) with corundum grit before spraying, and then an ultrasonic cleaner (Kunshan Ultrasonic Instruments Company Ltd., Kunshan, China) was used with acetone to clean the residual sand from the composite coating surface. The composition of each composite coating is presented in Table 1 . The thickness of the composite coatings was $300 \pm 20 \mu \mathrm{m}$. The thickness of the composite coatings was measured by the method of microscopically examining the cross-sections. Table 2 presents the spraying parameters. Scanning electron microscopy (FE-SEM, Tescan Mira 3, Bron, Kohoutovice, Czech Republic) was used to characterize the morphologies of the powders and composite coatings. The chemical composition of composite coatings was analyzed using an X'Pert-MRD X-ray diffractometer (Philips, Eindhoven, the Netherlands). A microhardness tester (MH-5-VM, Shanghai Hengyi Science and Technology, Shanghai, China) was used to measure the microhardness of composite coatings. The load was $300 \mathrm{~g}$. The dwell time was $5 \mathrm{~s}$.

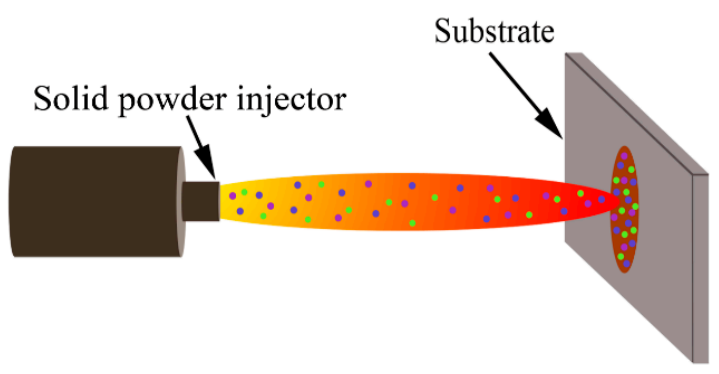

Figure 1. Schematic of the preparation of composite coatings.

Table 1. Composition of NiAl matrix composite coatings.

\begin{tabular}{cccc}
\hline Composite Coating & $\mathrm{NiAl}(w \mathrm{w} . \%)$ & $\mathrm{Cr}_{\mathbf{2}} \mathbf{O}_{3}$ (wt.\%) & Mo (wt.\%) \\
\hline NA & 100 & 0 & 0 \\
NA1 & 80 & 20 & 0 \\
NA2 & 70 & 20 & 10 \\
\hline
\end{tabular}


Table 2. Spraying parameters.

\begin{tabular}{cc}
\hline Parameter & Value \\
\hline Plasma gas flow $\mathrm{Ar}, \mathrm{L} / \mathrm{min}$ & 40 \\
Secondary gas flow $\mathrm{H}_{2}, \mathrm{~L} / \mathrm{min}$ & 5 \\
Spraying angle & $90^{\circ}$ \\
Powder feed rate, g/min & 40 \\
Current, A & 500 \\
Voltage, $\mathrm{V}$ & 60 \\
Spray distance, $\mathrm{mm}$ & 110 \\
\hline
\end{tabular}

\subsection{Tribocorrosion Tests}

A reciprocating ball-on-disk tribometer (UMT, Karlsruhe, Germany) was used to measure the tribocorrosion properties of the composite coatings in artificial seawater. The artificial seawater was prepared according the ASTM D114-98 standard [8]. To adjust the artificial seawater pH value to $8.2,0.1 \mathrm{M} \mathrm{NaOH}$ was used. Table 3 presents the artificial seawater's chemical composition. Figure 2 showed the reciprocating ball-on-disc tribometer's schematic. The solution cell material was polytetrafluoroethylene (PTFE), which presented excellent corrosion resistance and effectively avoided the environmental effect, according to the experiment results. The $\mathrm{Al}_{2} \mathrm{O}_{3}$ ceramic ball was used as the counter ball. The diameter of the $\mathrm{Al}_{2} \mathrm{O}_{3}$ ceramic ball was $5 \mathrm{~mm}$. Firstly, the composite coatings were polished until the composite coating surface roughness was below $0.5 \mu \mathrm{m}$. The tribocorrosion tests have been described in detail elsewhere [34].

Table 3. Artificial seawater's chemical composition.

\begin{tabular}{cc}
\hline Constituent & Concentration $(\mathrm{g} / \mathrm{L})$ \\
\hline $\mathrm{NaCl}$ & 24.530 \\
$\mathrm{Na}_{2} \mathrm{SO}_{4}$ & 4.090 \\
$\mathrm{CaCl}_{2}$ & 1.160 \\
$\mathrm{MgCl}{ }_{2} \cdot 6 \mathrm{H}_{2} \mathrm{O}$ & 11.110 \\
$\mathrm{KCl}$ & 0.695 \\
$\mathrm{NaHCO}$ & 0.201 \\
$\mathrm{KBr}_{3}$ & 0.100 \\
$\mathrm{H}_{3} \mathrm{BO}_{3}$ & 0.027 \\
$\mathrm{SrCl}_{2} \cdot 6 \mathrm{H}_{2} \mathrm{O}$ & 0.042 \\
$\mathrm{NaF}$ & 0.003 \\
\hline
\end{tabular}

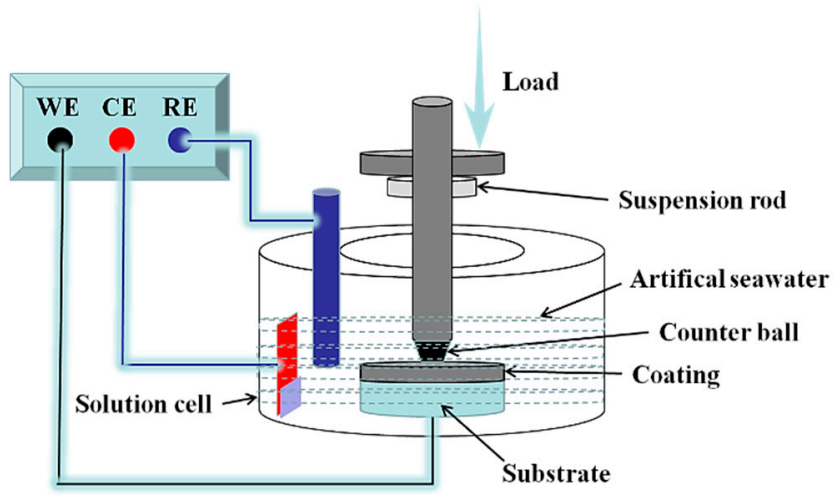

Figure 2. Reciprocating ball-on-disc tribometer's schematic. 


\section{Results and Discussion}

\subsection{Microstructure and Microhardness of Composite Coatings}

Figure 3 shows the SEM morphologies of spray powders. The NiAl and Mo powders were fabricated by gas-atomization and present the spherical shape. The size of the powders was around 50-100 $\mu \mathrm{m}$. The feedstock powder of $\mathrm{Cr}_{2} \mathrm{O}_{3}$ is fabricated by sintering and crushing and shows an angular shape. The size of the $\mathrm{Cr}_{2} \mathrm{O}_{3}$ was $5-53 \mu \mathrm{m}$. All feedstock powders are mingled mechanically before spraying, in order to make sure the powders distribute uniformly [35].
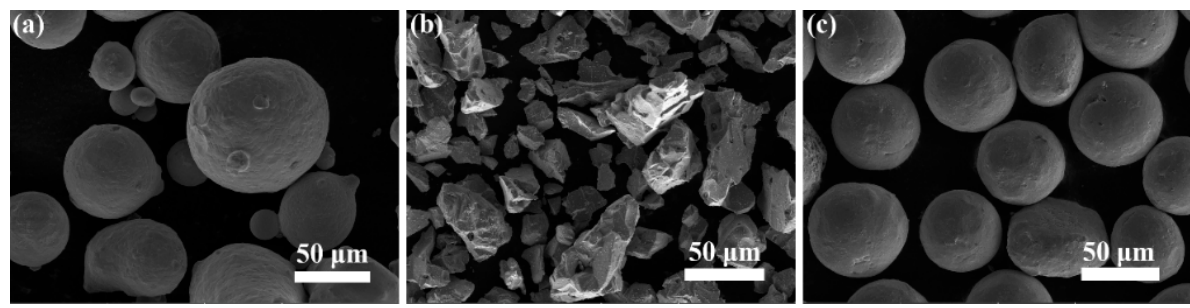

Figure 3. SEM morphologies of spray powders: (a) NiAl, (b) $\mathrm{Cr}_{2} \mathrm{O}_{3}$ and (c) Mo.

Figure 4 gives SEM images of a polished cross-section of NiAl matrix composite coatings. The composite coatings contain many defects (cracks and pores) (Figure 4a), and present the typical lamellar structure. Combining energy disperse spectroscopy (EDS) and X-ray diffraction (XRD) (Figure 5), the black phase is $\mathrm{Cr}_{2} \mathrm{O}_{3}$ and the gray phase is Mo in the composite coatings. The $\mathrm{Cr}_{2} \mathrm{O}_{3}$ and Mo phases distribute uniformly, and the interface of these two phases has no evident cracks.
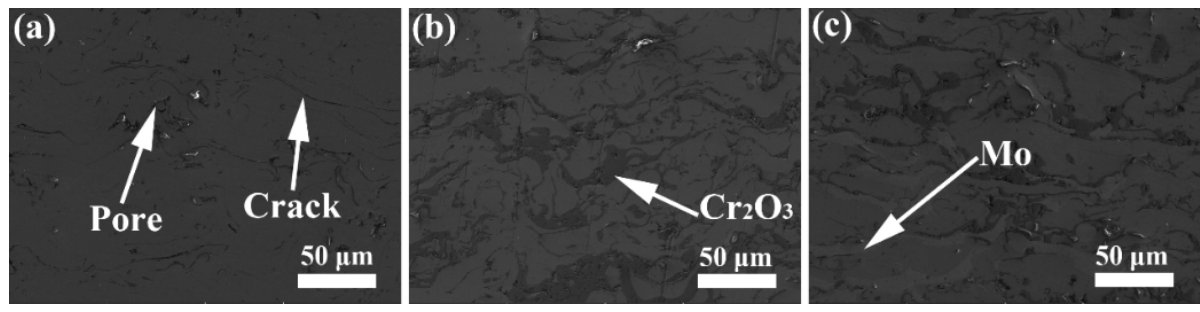

Figure 4. SEM images of polished cross-section of NiAl matrix composite coatings: (a) NA, (b) NA1 and (c) NA2.

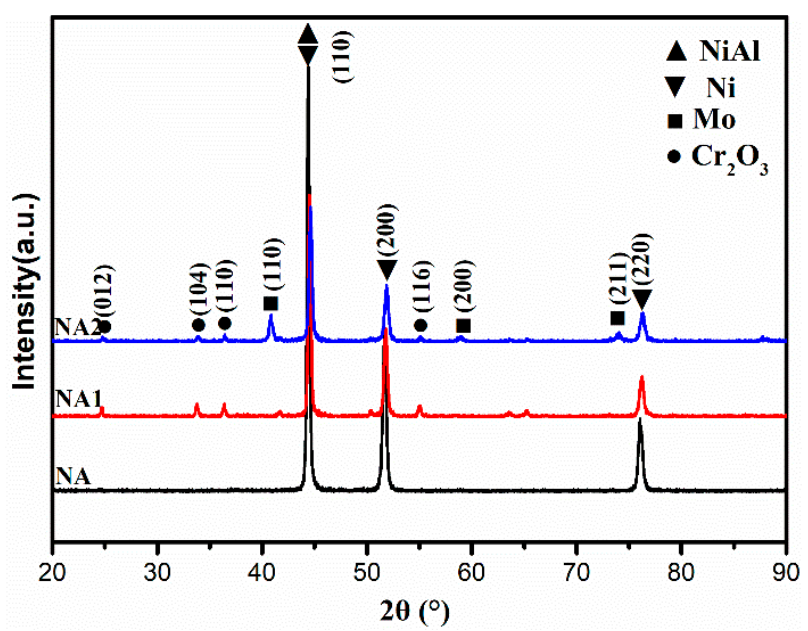

Figure 5. XRD patterns of $\mathrm{NiAl}$ matrix composite coatings.

Figure 5 presents the XRD patterns of NiAl matrix composite coatings. All composite coatings contain the Ni-based solid solution (JCPDS file no. 04-0850) and NiAl (JCPDS file no. 20-0019). The 
XRD spectrum of NA1 and NA2 composite coatings contains the diffraction peaks of $\mathrm{Cr}_{2} \mathrm{O}_{3}$ (JCPDS file no. 38-1479) and single-phase Mo (JCPDS file no. 42-1120). It is surprising that the diffraction peaks of Ni-based solid solution slightly shift to the right after addition of the Mo, which may be due to the partial solid solution of Mo in the matrix [36].

Table 4 gives the microhardness of composite coatings. The microhardness of composite coatings increased with the addition of $\mathrm{Cr}_{2} \mathrm{O}_{3}$ and Mo. The addition of $\mathrm{Cr}_{2} \mathrm{O}_{3}$ makes the microhardness of the composite coating increase from 195.1 to $290.5 \mathrm{HV}$. The $\mathrm{Cr}_{2} \mathrm{O}_{3}$ often acts as a strengthening hard phase, which could effectively enhance the hardness of materials [37,38]. So, the microhardness of the composite coating is obviously improved. The NA2 composite coating has the highest microhardness, of $362.2 \mathrm{HV}$ in all composite coatings. The Mo could act as the solution-strengthening phase, to greatly increase the microhardness of the composite coatings [39].

Table 4. Microhardness of composite coatings.

\begin{tabular}{cccc}
\hline Coatings & NA & NA1 & NA2 \\
\hline Vickers hardness (HV) & $195.1 \pm 13.6$ & $290.5 \pm 15.8$ & $362.2 \pm 16.9$ \\
\hline
\end{tabular}

\subsection{Electrochemical Behavior of Composite Coatings}

Figure 6 shows the open circuit potential (OCP) evolution before, during and after the tribocorrosion of composite coatings in artificial seawater. During the first half hour, the composite coatings were immersed in artificial seawater before sliding. The initial highest OCP value, before sliding, was for NA1. When the counter ball of $\mathrm{Al}_{2} \mathrm{O}_{3}$ started sliding on the sample surface, the OCP of all composite coatings shifted rapidly to the negative. The OCP of the NA coating is more negative than that of the NA1 and NA2 coatings. After adding the element Mo, the Mo partially dissolved in the matrix, resulting the effect of solid solution-strengthening in the composite coating. It is very helpful if the coating forms a dense rust layer on the composite coating surface during the first half hour of immersion in artificial seawater [12]. This dense rust layer is very difficult to destroy in the sliding process. So, the OCP of the NA2 coating is the most positive in the process of sliding. The OCP values of all the composite coatings start to gradually increase when the sliding stops, which plays the main role in deciding the OCP value. The addition of Mo makes it easier for NA2 to form a dense, passive film, leading the OCP of this sample having the highest value after sliding.

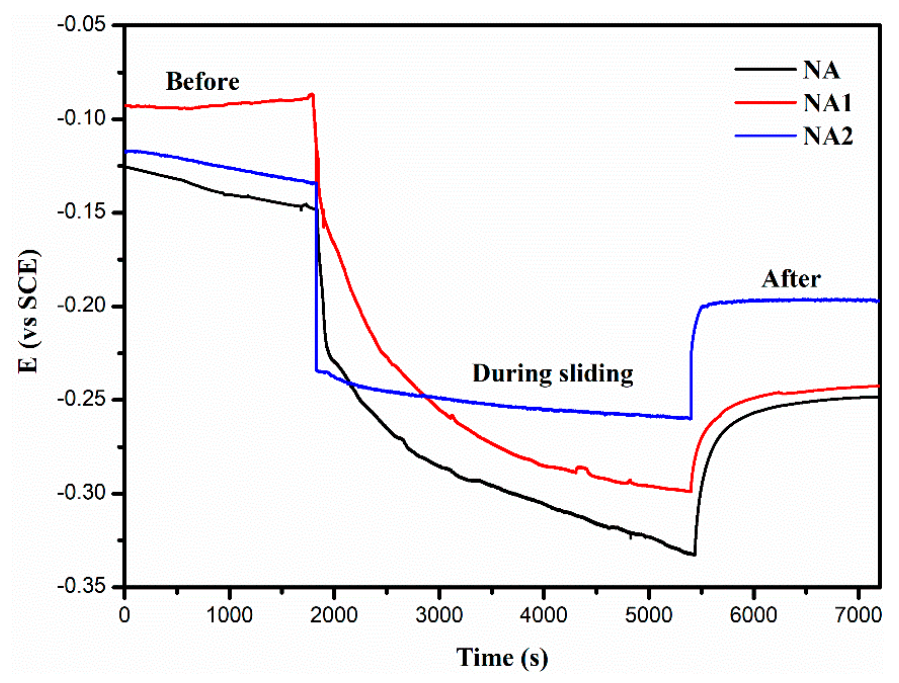

Figure 6. OCP evolution before, during and after tribocorrosion of composite coatings in artificial seawater. 
Figure 7 presents the potentiodynamic polarization curves of composite coatings sliding in artificial seawater. Basic parameters (corrosion current density $\left(i_{\text {corr }}\right)$, corrosion potential $\left(E_{\text {corr }}\right)$, anodic and cathodic Tafel slopes $\left(\beta_{a}\right.$ and $\left.\beta_{c}\right)$ of the composite coatings are listed in Table 5, measured from Figure 7 , using the Tafel extrapolation method. The polarization resistance value $\left(R_{p}\right)$ is calculated using the Stern-Geary equation:

$$
R_{P}=\frac{\beta_{a} \times \beta_{c}}{2.303 i_{\text {corr }}\left(\beta_{a}+\beta_{c}\right)}
$$

The results show that the corrosion potential ( $\left.E_{\text {corr }}\right)$ of the NA2 composite coating is $-0.490 \mathrm{~V}$ (vs. saturated calomel electrode (SCE)) and obviously higher than that of the NA and NA1 composite coatings of $-0.583 \mathrm{~V}$ (vs. SCE) and $-0.552 \mathrm{~V}$ (vs. SCE). The NA2 composite coating has the highest corrosion potential value of all composite coatings. Still, the corrosion current density $\left(i_{\text {corr }}\right)$ of the NA2 composite coating, at $9.487 \times 10^{-6} \mathrm{~A} / \mathrm{cm}^{2}$, is lower than that of NA and NA1 composite coatings, at $8.896 \times 10^{-5}$ and $4.624 \times 10^{-5} \mathrm{~A} / \mathrm{cm}^{2}$, respectively, indicating that the NA2 composite coating presents the best corrosion resistance and is very difficult to corrode. Generally speaking, corrosion current density is an important criterion in valuing the corrosion resistance of materials [8,40]. So, the NA2 composite coating presents lower corrosion rates than those of the NA and NA1 composite coatings, and may be very hard to corrode. At the same time, the NA2 composite coating has the highest $R_{p}$ of $9.003 \times 10^{2} \Omega$, which further illustrates that the NA2 composite coating presents very strong corrosion resistance under artificial seawater. In general, the $\beta_{a}$ is higher than $\beta_{c}$ of the material $[4,7,11,41]$. In this test result, the $\beta_{a}$ of all composite coatings are higher than the $\beta_{c}$. This kind of phenomenon is related to the fact that the cathodic part exchange-current density value is higher than that of the anodic part. The entire kinetics of the corrosion of all composite coatings are decided by the anodic part [11]. That is to say, the anodic dissolution rate is slower than that of the cathodic reaction.

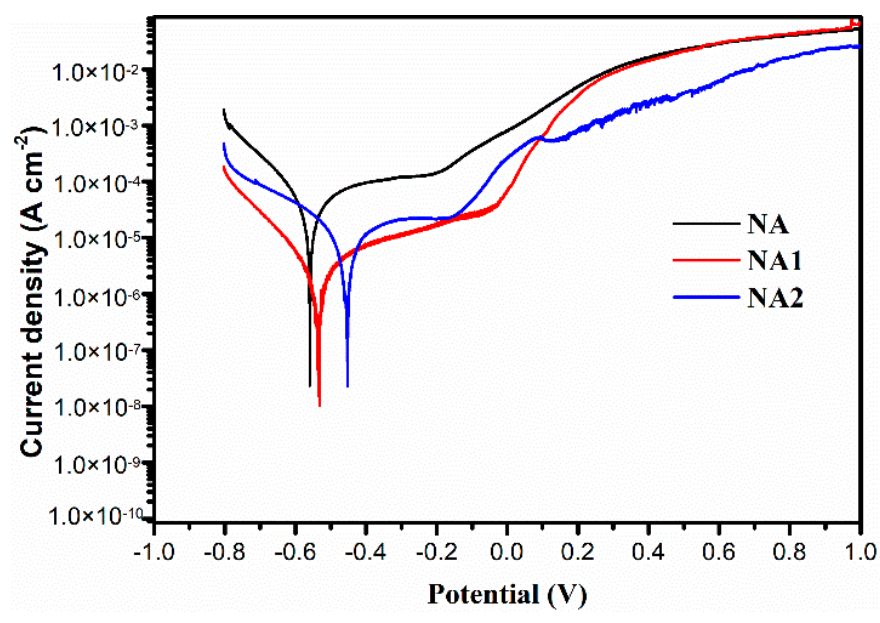

Figure 7. Potentiodynamic polarization curves of composite coatings sliding in artificial seawater.

Table 5. Corrosion parameters of composite coatings from potentiodynamic polarization curves.

\begin{tabular}{cccccc}
\hline Coatings & $E_{\text {corr }}(\mathrm{V}$, vs. SCE $)$ & $\boldsymbol{i}_{\text {corr }}\left(\mathrm{A} / \mathrm{cm}^{\mathbf{2}}\right)$ & $\boldsymbol{\beta}_{\boldsymbol{a}}(\mathrm{V} / \mathbf{d e c})$ & $-\boldsymbol{\beta}_{\boldsymbol{c}}(\mathrm{V} / \mathrm{dec})$ & $\boldsymbol{R}_{\boldsymbol{p}}(\boldsymbol{\Omega})$ \\
\hline NA & -0.583 & $8.896 \times 10^{-5}$ & 0.059 & 0.046 & $1.262 \times 10^{2}$ \\
NA1 & -0.552 & $4.624 \times 10^{-5}$ & 0.050 & 0.042 & $2.143 \times 10^{2}$ \\
NA2 & -0.490 & $9.487 \times 10^{-6}$ & 0.042 & 0.037 & $9.003 \times 10^{2}$ \\
\hline
\end{tabular}

\subsection{Tribological Behavior of NiAl Matrix Composite Coatings}

Figure 8 shows the friction curves and wear rate of the NiAl matrix composite coatings in artificial seawater. Obviously, the friction coefficient and wear rate of the NA2 composite coating, of 0.18 and $3.63 \times 10^{-6} \mathrm{~mm}^{3} / \mathrm{Nm}$, respectively, are the lowest of all the composite coatings. This result is probably 
due to the way $\mathrm{Cr}_{2} \mathrm{O}_{3}$ acts as a strengthening hard phase, to enhance the hardness and wear resistance properties of composite coatings effectively. Meanwhile, the Mo could dissolve in the matrix and has a solid solution-strengthening effect in the NA2 composite coating. These are very useful in helping form the dense rust layer on the worn surface of the NA2 composite coating, which effectively reduces the corrosion rate, friction coefficient and wear rate of the NA2 composite coating.
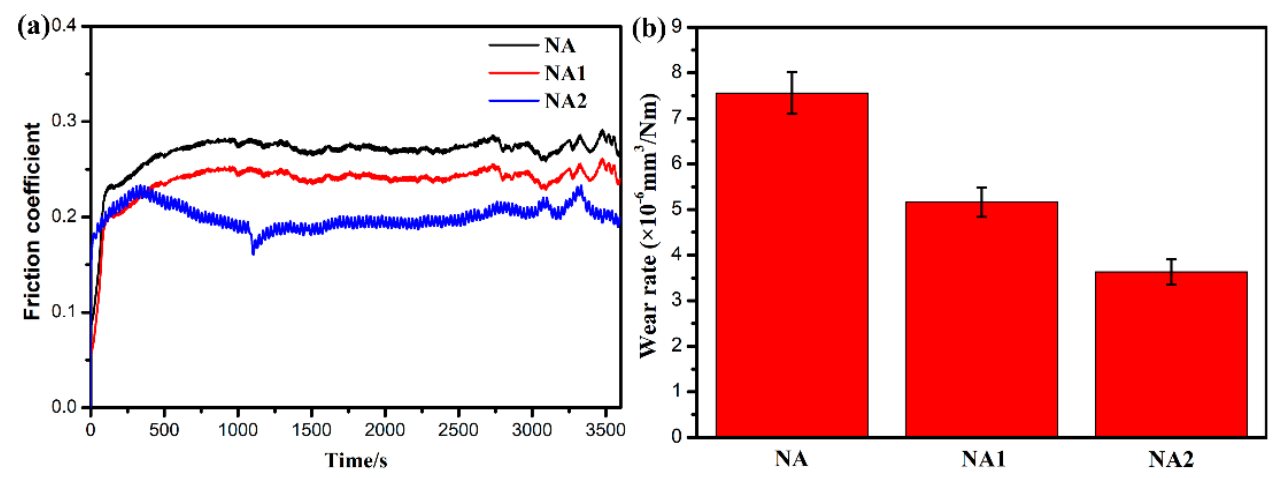

Figure 8. Friction curves (a) and wear rate (b) of NiAl matrix composite coatings.

In order to further investigate the tribocorrosion behavior of $\mathrm{NiAl}$ matrix composite coatings in artificial seawater, a color 3D laser scanning microscope was used. Figure 9 gives the 3D profiles of worn surfaces of $\mathrm{NiAl}$ matrix composite coatings after being tested in artificial seawater. The NA2 composite coating worn track is, at $118.9 \mu \mathrm{m}$, narrower than the NA and NA1 composite coatings, at 189.6 and $136.3 \mu \mathrm{m}$, respectively. This observation is in accordance with the friction coefficient and wear rate results of NiAl matrix composite coatings (Figure 8). Meanwhile, the worn surface of the NA coating suffered very severe corrosion. However, the worn surfaces of NA1 and NA2 composite coatings display slight corrosion. This result is similar with that of the corrosion current densities of the composite coatings (Table 5). Corrosion could aggravate the wear rate of the NiAl matrix composite coatings. So, the NA coating presents the highest wear rate and the NA2 coating has the lowest wear rate (Figure 8). It further illustrates that, in artificial seawater, the NA2 composite coating presents excellent tribocorrosion properties.
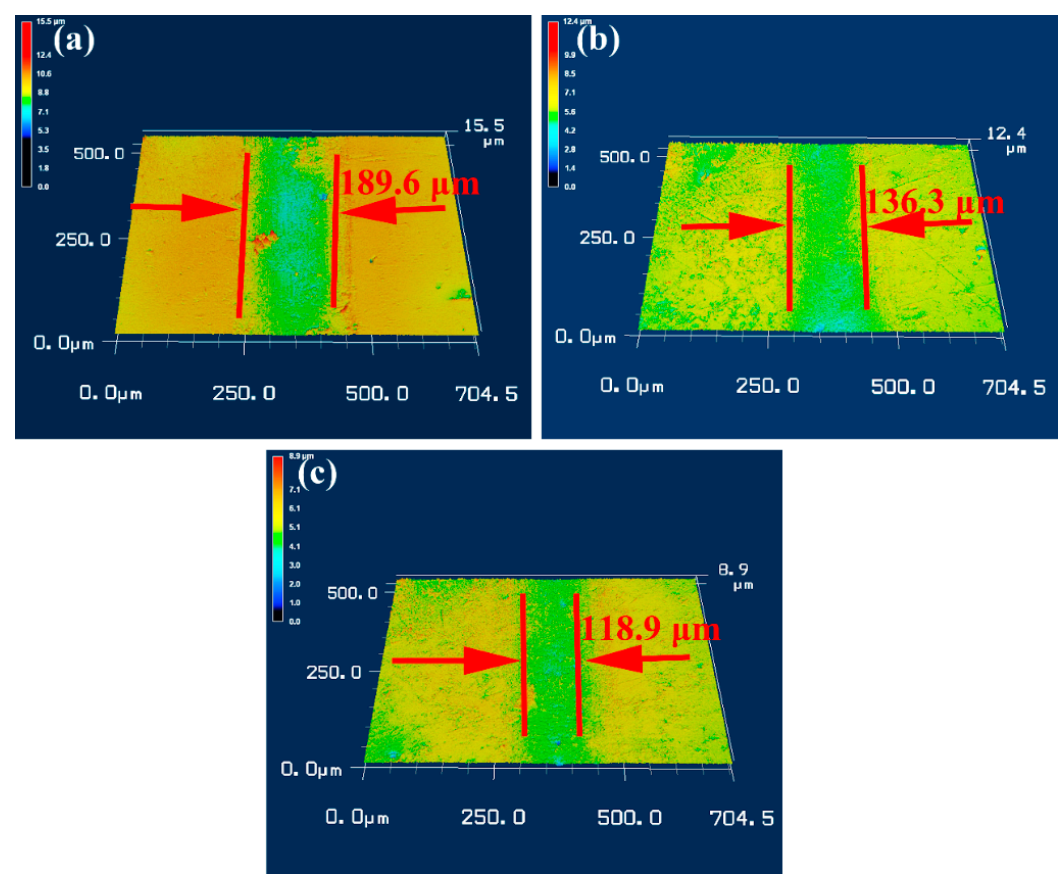

Figure 9. 3D profiles of worn surfaces of NiAl matrix composite coatings: (a) NA, (b) NA1 and (c) NA2. 
Figure 10 presents the SEM morphologies of composite coating worn surfaces during sliding. The NA coating displayed poor corrosion performance at cracks and pores (Figure 10a). The coating with the addition of $\mathrm{Cr}_{2} \mathrm{O}_{3}$ and Mo had visibly less corrosion than those of any other coatings (Figure 10c). It is probably due to the way Mo acts as a solution-strengthening phase, which could enhance the strength of materials [24-26].
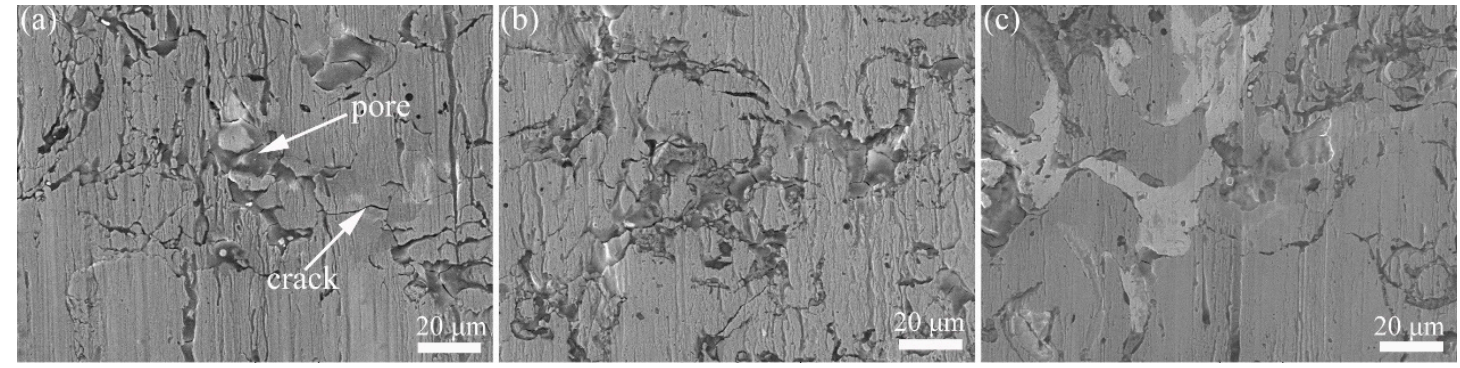

Figure 10. SEM morphologies of composite coating worn surfaces: (a) NA, (b) NA1 and (c) NA2.

\section{Conclusions}

In this study, composite coatings were fabricated using APS. The mechanical and tribocorrosion properties of composite coatings incorporated with $\mathrm{Cr}_{2} \mathrm{O}_{3}$ and Mo in artificial seawater were investigated, and the synergistic effect between corrosion and wear were investigated in detail. The main conclusions are given as follows:

- Upon adding $\mathrm{Cr}_{2} \mathrm{O}_{3}$ and Mo, the microhardness of the composite coatings improves from 195.1 to 362.2 HV. Meanwhile, the $\mathrm{Cr}_{2} \mathrm{O}_{3}$ and Mo phases distribute uniformly and the interface of these two phases has no evident cracks.

- The Ni-based solid solution diffraction peaks slightly shift to the right after the addition of Mo, which is maybe due to the partial solid solution of the element Mo into the matrix.

- The NiAl- $\mathrm{Cr}_{2} \mathrm{O}_{3}-\mathrm{Mo}$ composite coating has the lowest corrosion current density, friction coefficient and wear rate of $9.487 \times 10^{-6} \mathrm{~A} / \mathrm{cm}^{2}, 0.18$ and $3.63 \times 10^{-6} \mathrm{~mm}^{3} / \mathrm{Nm}$ in all composite coatings.

- The NiAl- $\mathrm{Cr}_{2} \mathrm{O}_{3}-\mathrm{Mo}$ composite coating shows excellent tribocorrosion properties in artificial seawater.

Author Contributions: Writing—original draft preparation, B.L.; writing-review and editing, C.L.; project administration, Y.G.; visualization, H.G.; data curation, Y.K.; formal analysis, S.Z.

Funding: This research was funded by the National Natural Science Foundation of China (Grant Nos. 51805408, 51665026), the Natural Science Foundation of Shaanxi Province (Grant No. 2019JQ-283), the China Postdoctoral Science Foundation (Grant No. 2019M653597), the Shaanxi Province Postdoctoral Science Foundation, the Fundamental Research Funds for Central Universities (Grant Nos. xzy012019010, xtr0118008), the Guangxi Innovation Driven Development Project (Grant No. GUIKEAA18242001) and the Guangdong Province Key Area R\&D Program (Grant No. 2019B010942001).

Conflicts of Interest: The authors declare no conflict of interest.

\section{References}

1. Aribo, S.; Fakorede, A.; Ige, O.; Olubambi, P. Erosion-corrosion behaviour of aluminum alloy 6063 hybrid composite. Wear 2017, 376-377, 608-614. [CrossRef]

2. Babu, P.; Sen, D.; Jyothirmayi, A.; Krishna, L.; Rao, D. Influence of microstructure on the wear and corrosion behavior of detonation sprayed $\mathrm{Cr}_{2} \mathrm{O}_{3}-\mathrm{Al}_{2} \mathrm{O}_{3}$ and plasma sprayed $\mathrm{Cr}_{2} \mathrm{O}_{3}$ coatings. Ceram. Int. 2018, 44 , 2351-2357. [CrossRef]

3. Bai, W.; Xie, Y.; Li, L.; Wang, X.; Gu, C.; Tu, J. Tribological and corrosion behaviors of Zr-doped graphite-like carbon nanostructured coatings on Ti6Al4V alloy. Surf. Coat. Technol. 2017, 320, 235-239. [CrossRef] 
4. Castillejo, F.; Marulanda, D.; Olaya, J.; Alfonso, J. Wear and corrosion resistance of niobium-chromium carbide coatings on AISI D2 produced through TRD. Surf. Coat. Technol. 2014, 254, 104-111. [CrossRef]

5. Dehghanghadikolaei, A.; Ibrahim, H.; Amerinatanzi, A.; Hashemi, M.; Moghaddam, N.; Elahinia, M. Improving corrosion resistance of additively manufactured nickel-titanium biomedical devices by micro-arc oxidation process. J. Mater. Sci. 2019, 54, 7333-7355. [CrossRef]

6. Dalibón, E.; Escalada, L.; Simison, S.; Forsich, C.; Heim, D.; Bruhl, S. Mechanical and corrosion behavior of thick and soft DLC coatings. Surf. Coat. Technol. 2017, 312, 101-109. [CrossRef]

7. Fotovvati, B.; Namdari, N.; Dehghanghadikolaei, A. On coating techniques for surface protection: A review. J. Manuf. Mater. Process. 2019, 3, 28. [CrossRef]

8. Liu, X.; Zhao, X.; An, Y.; Hou, G.; Li, S.; Deng, W.; Zhou, H.; Chen, J. Effects of loads on corrosion-wear synergism of NiCoCrAlYTa coating in artificial seawater. Tribol. Int. 2018, 118, 421-431. [CrossRef]

9. Dun, Y.; Zhao, X.; Tang, Y.; Dino, S.; Zuo, Y. Microstructure and corrosion resistance of a fluorosilane modified silane-graphene film on 2024 aluminum alloy. Appl. Surf. Sci. 2018, 437, 152-160. [CrossRef]

10. Silva, R.; Nogueira, R.; Bastos, I. Tribocorrosion of UNS S32750 in chloride medium: Effect of the load level. Electrochim. Acta 2011, 56, 8839-8845. [CrossRef]

11. Liu, X.; An, Y.; Li, S.; Zhao, X.; Hou, G.; Zhou, H.; Chen, J. An assessment of tribological performance on NiCoCrAlYTa coating under corrosive environments. Tribol. Int. 2017, 115, 35-44. [CrossRef]

12. Ma, F.; Li, J.; Zeng, Z.; Gao, Y. Structural, mechanical and tribocorrosion behaviour in artificial seawater of CrN/AlN nano-multilayer coatings on F690 steel substrates. Appl. Surf. Sci. 2018, 428, 404-414. [CrossRef]

13. Buciumeanu, M.; Bagheri, A.; Souza, J.; Silva, F.; Henriques, B. Tribocorrosion behavior of hot pressed CoCrMo alloys in artificial saliva. Tribol. Int. 2016, 97, 423-430. [CrossRef]

14. Mischler, S. Triboelectrochemical techniques and interpretation methods in tribocorrosion: A comparative evaluation. Tribol. Int. 2008, 41, 573-583. [CrossRef]

15. Chen, Q.; Xie, Z.; Chen, T.; Gong, F. Tribocorrosion failure mechanism of $\mathrm{TiN}^{\mathrm{S}} \mathrm{SiO} \mathrm{O}_{x}$ duplex coating deposited on AISI304 stainless steel. Materials 2016, 9, 963. [CrossRef]

16. Adabi, M.; Amadeh, A. Formation mechanisms of Ni-Al intermetallics during heat treatment of Ni coating on 6061 Al substrate. Trans. Nonferrous Met. Soc. China 2015, 25, 3959-3966. [CrossRef]

17. Ameri, S.; Sadeghian, Z.; Kazeminezhad, I. Effect of CNT addition approach on the microstructure and properties of NiAl-CNT nanocomposites produced by mechanical alloying and spark plasma sintering. Intermetallics 2016, 76, 41-48. [CrossRef]

18. Beyhaghi, M.; Kashefi, M.; Kiani-Rashid, A.; Khaki, J.; Jonsson, S. In-situ synthesis of nanostructured $\mathrm{NiAl}-\mathrm{Al}_{2} \mathrm{O}_{3}$ composite coatings on cast iron substrates by spark plasma sintering of mechanically activated powders. Surf. Coat. Technol. 2015, 272, 254-267. [CrossRef]

19. Li, B.; Jia, J.; Gao, Y.; Han, M.; Wang, W. Microstructural and tribological characterization of NiAl matrix self-lubricating composite coatings by atmospheric plasma spraying. Tribol. Int. 2017, 109, 563-570. [CrossRef]

20. Liu, E.; Bai, Y.; Gao, Y.; Yi, G.; Jia, J. Tribological properties of NiAl-based composites containing $\mathrm{Ag}_{3} \mathrm{VO}_{4}$ nanoparticles at elevated temperatures. Tribol. Int. 2014, 80, 25-33. [CrossRef]

21. Geist, D.; Gammer, C.; Rentenberger, C.; Karnthaler, H. Sessile dislocations by reactions in NiAl severely deformed at room temperature. J. Alloy. Compd. 2015, 621, 371-377. [CrossRef] [PubMed]

22. Hsiao, W.; Su, C.; Huang, T.; Liao, W. The microstructural characteristics and mechanical properties of $\mathrm{Ni}-\mathrm{Al} / \mathrm{h}-\mathrm{BN}$ coatings deposited using plasma spraying. J. Alloy. Compd. 2011, 509, 8239-8245. [CrossRef]

23. Liu, E.; Jia, J.; Bai, Y.; Wang, W.; Gao, Y. Study on preparation and mechanical property of nanocrystalline NiAl intermetallic. Mater. Des. 2014, 53, 596-601. [CrossRef]

24. Guo, X.; Niu, Y.; Huang, L.; Ji, H.; Zheng, X. Microstructure and tribological property of TiC-Mo composite coating prepared by vacuum plasma spraying. J. Therm. Spray Technol. 2012, 21, 1083-1090. [CrossRef]

25. Klimashin, F.; Euchner, H.; Mayrhofer, P. Computational and experimental studies on structure and mechanical properties of Mo-Al-N. Acta Mater. 2016, 107, 273-278. [CrossRef]

26. Kong, L.; Bi, Q.; Zhu, S.; Qiao, Z.; Yang, J.; Liu, W. Effect of $\mathrm{CuO}$ on self-lubricating properties of $\mathrm{ZrO}_{2}\left(\mathrm{Y}_{2} \mathrm{O}_{3}\right)-$ Mo composites at high temperatures. J. Eur. Ceram. Soc. 2014, 34, 1289-1296. [CrossRef]

27. Liu, E.; Gao, Y.; Bai, Y.; Yi, G.; Wang, W.; Zeng, Z.; Jia, J. Tribological properties of self-lubricating $\mathrm{NiAl} / \mathrm{Mo}-$ based composites containing $\mathrm{AgVO}_{3}$ nanowires. Mater. Charact. 2014, 97, 116-124. [CrossRef] 
28. Liu, E.; Gao, Y.; Jia, J.; Bai, Y.; Wang, W. Microstructure and mechanical properties of in situ $\mathrm{NiAl}_{-} \mathrm{Mo}_{2} \mathrm{C}$ nanocomposites prepared by hot-pressing sintering. Mater. Sci. Eng. A 2014, 592, 201-206. [CrossRef]

29. Zhu, S.; Bi, Q.; Niu, M.; Yang, J.; Liu, W. Tribological behavior of NiAl matrix composites with addition of oxides at high temperatures. Wear 2012, 274, 423-434. [CrossRef]

30. Navas, C.; Cadenas, M.; Cuetos, J.; Damborenea, J. Microstructure and sliding wear behaviour of Tribaloy T-800 coatings deposited by laser cladding. Wear 2006, 260, 838-846. [CrossRef]

31. Du, L.; Zhang, W.; Zhang, W.; Zhang, T.; Lan, H.; Huang, C. Tribological and oxidation behaviors of the plasma sprayed NiCoCrAlY-Cr${ }_{2} \mathrm{O}_{3}-\mathrm{AgVO}_{3}$ coating. Surf. Coat. Technol. 2016, 298, 7-14. [CrossRef]

32. Kim, G.; Choi, H.; Han, C.; Uhm, S.; Lee, C. Characterization of atmospheric plasma spray $\mathrm{NiCr}_{-} \mathrm{Cr}_{2} \mathrm{O}_{3}-$ $\mathrm{Ag}-\mathrm{CaF}_{2} / \mathrm{BaF}_{2}$ coatings. Surf. Coat. Technol. 2005, 195, 107-115. [CrossRef]

33. Ramazani, M.; Ashrafizadeh, F.; Mozaffarinia, R. The influence of temperature on frictional behavior of plasma-sprayed NiAl- $\mathrm{Cr}_{2} \mathrm{O}_{3}$ based self-adaptive nanocomposite coatings. J. Therm. Spray Technol. 2013, 22, 1120-1132. [CrossRef]

34. Li, B.; Li, C.; Gao, Y.; Guo, H.; Kang, Y.; Zhao, S. Tribological performance of a Ni-based composite coating in artificial seawater. Coatings 2019, 7, 747. [CrossRef]

35. Li, B.; Gao, Y.; Jia, J.; Han, M.; Guo, H.; Wang, W. Influence of heat treatments on the microstructure as well as mechanical and tribological properties of NiCrAlY-Mo-Ag coatings. J. Alloy. Compd. 2016, 686, 503-510. [CrossRef]

36. Li, B.; Jia, J.; Han, M.; Gao, Y.; Wang, W.; Li, C. Microstructure, mechanical and tribological properties of plasma-sprayed NiCrAlY-Mo-Ag coatings from conventional and nanostructured powders. Surf. Coat. Technol. 2017, 324, 552-559. [CrossRef]

37. Zhang, T.; Lan, H.; Huang, C.; Du, L.; Zhang, W. Formation mechanism of the lubrication film on the plasma sprayed NiCoCrAlY-Cr${ }_{2} \mathrm{O}_{3}-\mathrm{AgMo}$ coating at high temperatures. Surf. Coat. Technol. 2017, 319, 47-54. [CrossRef]

38. Yang, H.; Lee, C.; Hwang, S. The effect of nano-sized $\mathrm{Cr}_{2} \mathrm{O}_{3}$ addition on the characteristics of $\mathrm{NiCr}^{-} \mathrm{Cr}_{2} \mathrm{O}_{3}-$ Ag- $\mathrm{BaF}_{2} / \mathrm{CaF}_{2}$ coating. Surf. Coat. Technol. 2006, 201, 38-44. [CrossRef]

39. Tian, J.; Yao, S.; Luo, X.; Li, C.; Li, C. An effective approach for creating metallurgical self-bonding in plasma-spraying of NiCr-Mo coating by designing shell-core-structured powders. Acta Mater. 2016, 110, 19-30. [CrossRef]

40. Zhang, R.; Wang, H.; Xing, X.; Yuan, Z.; Yang, S.; Han, Z.; Yuan, G. Effects of Ni addition on tribocorrosion property of TiCu alloy. Tribol. Int. 2017, 107, 39-47. [CrossRef]

41. Kannan, A.; Muralidharan, S.; Sarangapani, K.; Balaramachandran, V.; Kapali, V. Corrosion and anodic behaviour of zinc and its ternary alloys in alkaline battery electrolytes. J. Powder Sources 1995, 57, 93-98. [CrossRef]

(C) 2019 by the authors. Licensee MDPI, Basel, Switzerland. This article is an open access article distributed under the terms and conditions of the Creative Commons Attribution (CC BY) license (http://creativecommons.org/licenses/by/4.0/). 